U.S. Department of the Interior

U.S. Geological Survey

\title{
FISH-COMMUNITY COMPOSITION IN COWANESQUE RIVER UPSTREAM AND DOWNSTREAM OF THE COWANESQUE DAM, TIOGA COUNTY, PENNSYLVANIA, 1998
}

by Robin A. Brightbill and Michael D. Bilger

Open-File Report 99-208

prepared in cooperation with the

U.S. ARMY CORPS OF ENGINEERS

Lemoyne, Pennsylvania 1999 


\title{
U.S. DEPARTMENT OF THE INTERIOR
}

\author{
BRUCE BABBITT, Secretary
}

\section{U.S. GEOLOGICAL SURVEY}

\author{
Charles G. Groat, Director
}

For additional information write to:

\section{District Chief}

U.S. Geological Survey

840 Market Street

Lemoyne, Pennsylvania 17043-1586
Copies of this report may be purchased from:

U.S. Geological Survey

Branch of Information Services

Box 25286, Federal Center

Denver, Colorado 80225-0286 


\section{CONTENTS}

Page

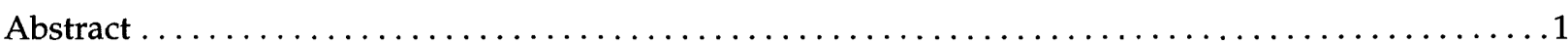

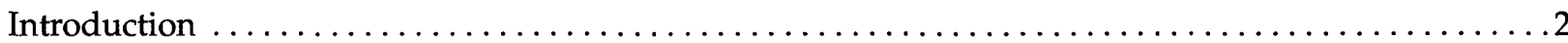

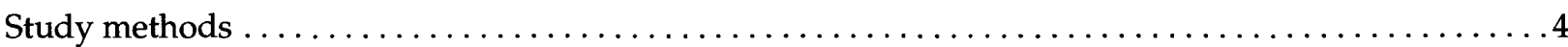

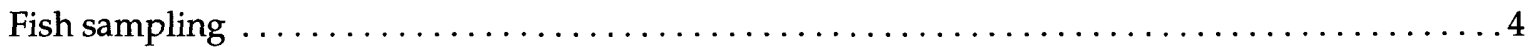

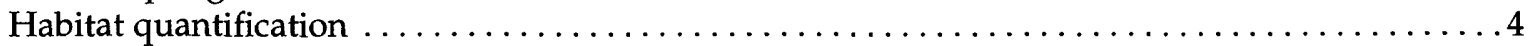

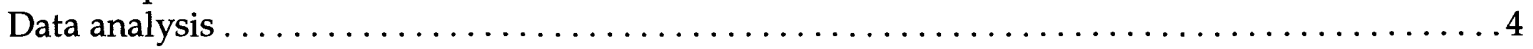

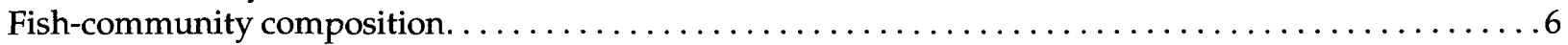

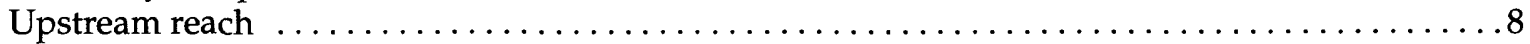

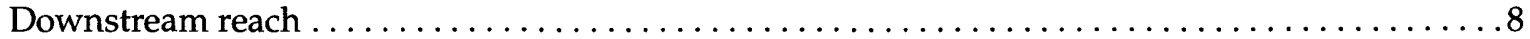

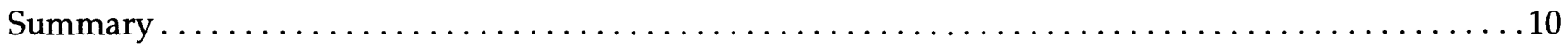

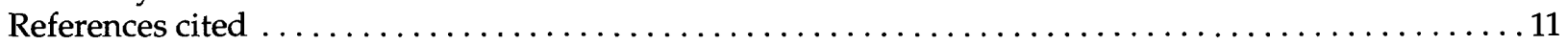

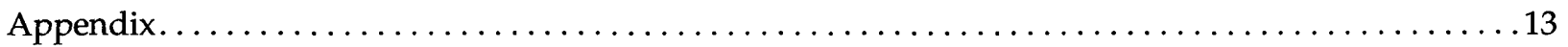

\section{ILLUSTRATIONS}

1. Map showing site location of reaches sampled for fish communities upstream and downstream of the Cowanesque Dam, Tioga County, Pa., 1998 . . . . . . . . . 3

\section{TABLES}

1. Taxa list, number of individuals, and total and average weights by species for fish communities upstream and downstream of Cowanesque Dam, $\mathrm{Pa}$.,

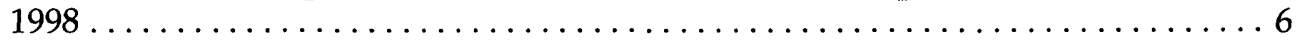

2. IBI score for fish communities upstream and downstream of Cowanesque Dam,

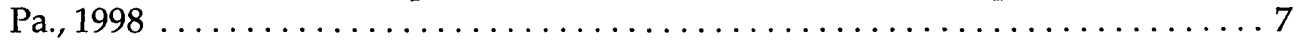

3. Habitat assessment upstream and downstream of Cowanesque Dam, Pa., 1998 . . . . 7 
CONVERSION FACTORS AND ABBREVIATIONS

Multiply

millimeter (mm)

meter $(\mathrm{m})$

kilometer (km)

square meter $\left(\mathrm{m}^{2}\right)$

square kilometer $\left(\mathrm{km}^{2}\right)$

gram (g)

degree Fahrenheit (F)
By

To obtain
Length

$\begin{array}{ll}0.03937 & \text { inch } \\ 3.281 & \text { foot } \\ 0.3861 & \text { mile }\end{array}$

Area

10.76

0.3861

Mass

0.03527

Temperature

${ }^{\circ} \mathrm{F}=1.8{ }^{\circ} \mathrm{C}+32$ square foot

square mile

ounce, avoirdupois

degree Celsius

Abbreviated water-quality units used in report:

$\mu \mathrm{S} / \mathrm{cm}$, microsiemens per centimeter at 25 degrees Celsius 


\title{
Fish-Community Composition in Cowanesque River Upstream and Downstream of the Cowanesque Dam, Tioga County, Pennsylvania, 1998
}

\author{
by Robin A. Brightbill and Michael D. Bilger
}

\begin{abstract}
The U.S. Army Corps of Engineers, Baltimore District, has been conducting biological surveys of the inflow and outflow streams of Cowanesque Lake since the early 1980's. The objective of these surveys is to identify possible detrimental effects as well as benefits of the reservoirs and to better understand the aquatic communities in the vicinity of the reservoirs at the present and over time. The U.S. Army Corps of Engineers and the U.S. Geological Survey jointly conducted a survey of the fish communities at Cowanesque River near Nelson, Pa. (inflow), and Cowanesque River near Lawrenceville, Pa. (outflow), in September 1998 to address community differences between reaches. A habitat assessment was conducted in accordance with the U.S. Environmental Protection Agency's Rapid Bioassessment Protocols to determine any possible habitat influence on fish communities located in these reaches.
\end{abstract}

The fish communities upstream and downstream of Cowanesque Lake are in good to fair condition; the Index of Biotic Integrity (IBI) scores are 4.3 and 3.8, respectively. An IBI developed for Maryland streams was used for the assessment because no IBI that is specifically applicable to Pennsylvania or New York is available, and the fauna in Maryland is more like that in Pennsylvania and New York than are fauna in Ohio and the Midwest, for which IBI's have been established, or the Northeast, where streams are species depauperate. The habitat conditions upstream and downstream were sub-optimal. These fish communities, however, were different; the Jaccard Coefficient was 0.32 , and the Index of Similarity was 0.48 . Upstream, 11 species were collected; 22 were collected downstream. The Shannon Index for the upstream sampling site was 2.69 and for the downstream site was 3.36.

Upstream of the reservoir, the bottom substrate was bedrock, cobble, and boulder. The geomorphic channel unit of the reach was riffle and pool. The fish species collected upstream are typical of streams with bedrock and boulders. The boulders are used for cover and protection. Downstream of the reservoir, the bottom substrate was cobble and gravel, and the geomorphic channel unit also was riffle and pool. Vegetation and woody snags provided a diversity of cover for the fish. The species collected downstream are typical of those found in lakes and in slower, deeper waters of rivers with aquatic vegetation. Upstream and downstream, the habitats are different. These differences are reflected by the fish communities present in the two reaches. The influence of the dam on these communities cannot be fully addressed without historical data but the reaches have different habitat and fish-community composition. 


\section{INTRODUCTION}

Biological surveys of streams in the vicinity of selected reservoirs were initiated in 1982 by the Baltimore District, U.S. Army Corps of Engineers (COE). The principal objectives of the surveys are to identify possible detrimental effects as well as benefits of the reservoirs, add to a database that was developed for monitoring the composition, abundance, diversity, and distribution of fishes over time, and provide a better understanding of the aquatic resources in the vicinity of the reservoirs.

The present study was a joint effort between the COE and the U.S. Geological Survey (USGS). An assessment of the habitat suitability for sustaining fish communities also was included in this study. The fish communities were sampled to determine community composition and to document any differences between the communities upstream and downstream of the reservoir.

Reaches were selected to correspond with existing COE macroinvertebrate reaches and previously sampled fish-community reaches. Each reach included a proportional representation of the available geomorphologic units for the stream. Two reaches, one upstream and one downstream of Cowanesque Dam, which was constructed in 1973 for the purpose of flood control (Ward, 1976), were chosen for the fish-community study (fig. 1). Release from the dam is through multilevel outlet works and over the spillway when flood levels are reached (Ward, 1976).

The upstream reach, Cowanesque River near Nelson, Pa. (latitude/longitude $=41^{\circ} 58^{\prime} 25^{\prime \prime} / 77^{\circ} 14^{\prime} 44^{\prime \prime}$ ), begins at the falls that flow into the reservoir and extends upstream $203 \mathrm{~m}(666 \mathrm{ft})$. The falls are a barrier that likely prevent fish migration from the reservoir into the upstream reach. The area sampled was approximately $2,934 \mathrm{~m}^{2}\left(31,687 \mathrm{ft}^{2}\right)$. The drainage area is $640 \mathrm{~km}^{2}\left(247 \mathrm{mi}^{2}\right)$. The geomorphic channel unit is riffle and pool. The reach bottom material is bedrock, cobble, and boulder. At the time of sampling, approximately 50 percent of the streambed appeared exposed following drought conditions. The left bank rises steeply; the flood plain is vegetated with a few trees and grasses. The right bank is a linear, gravel shoal that transitions into a thin riparian zone. The $\mathrm{pH}$ was 7.1 , temperature was $21^{\circ} \mathrm{C}$, and specific conductance was $403 \mu \mathrm{S} / \mathrm{cm}$.

The downstream reach, Cowanesque River near Lawrenceville, Pa. (latitude/longitude = $\left.42^{\circ} 00^{\prime} 07^{\prime \prime} / 77^{\circ} 07^{\prime} 35^{\prime \prime}\right)$, is $150 \mathrm{~m}$ (495 ft) downstream of the State Route 15 bridge outside of Lawrenceville,

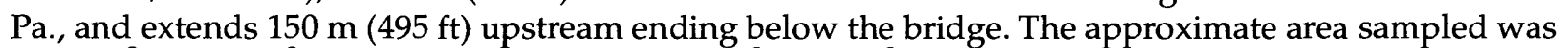
$4,150 \mathrm{~m}^{2}\left(44,820 \mathrm{ft}^{2}\right)$. The drainage area is $744 \mathrm{~km}^{2}\left(299 \mathrm{mi}^{2}\right)$. The geomorphic channel unit is riffle and pool. Substrate in the reach is cobble and gravel. None of the streambed was exposed. The left side of the stream is mostly riffle; towards the top of the reach is a pooled area under the bridge. The right side of the stream has woody snags, algal beds, and aquatic vegetation. The banks are vegetated with trees and grasses. The $\mathrm{pH}$ was 6.7 , temperature $19^{\circ} \mathrm{C}$, and specific conductance was $206 \mu \mathrm{S} / \mathrm{cm}$. 


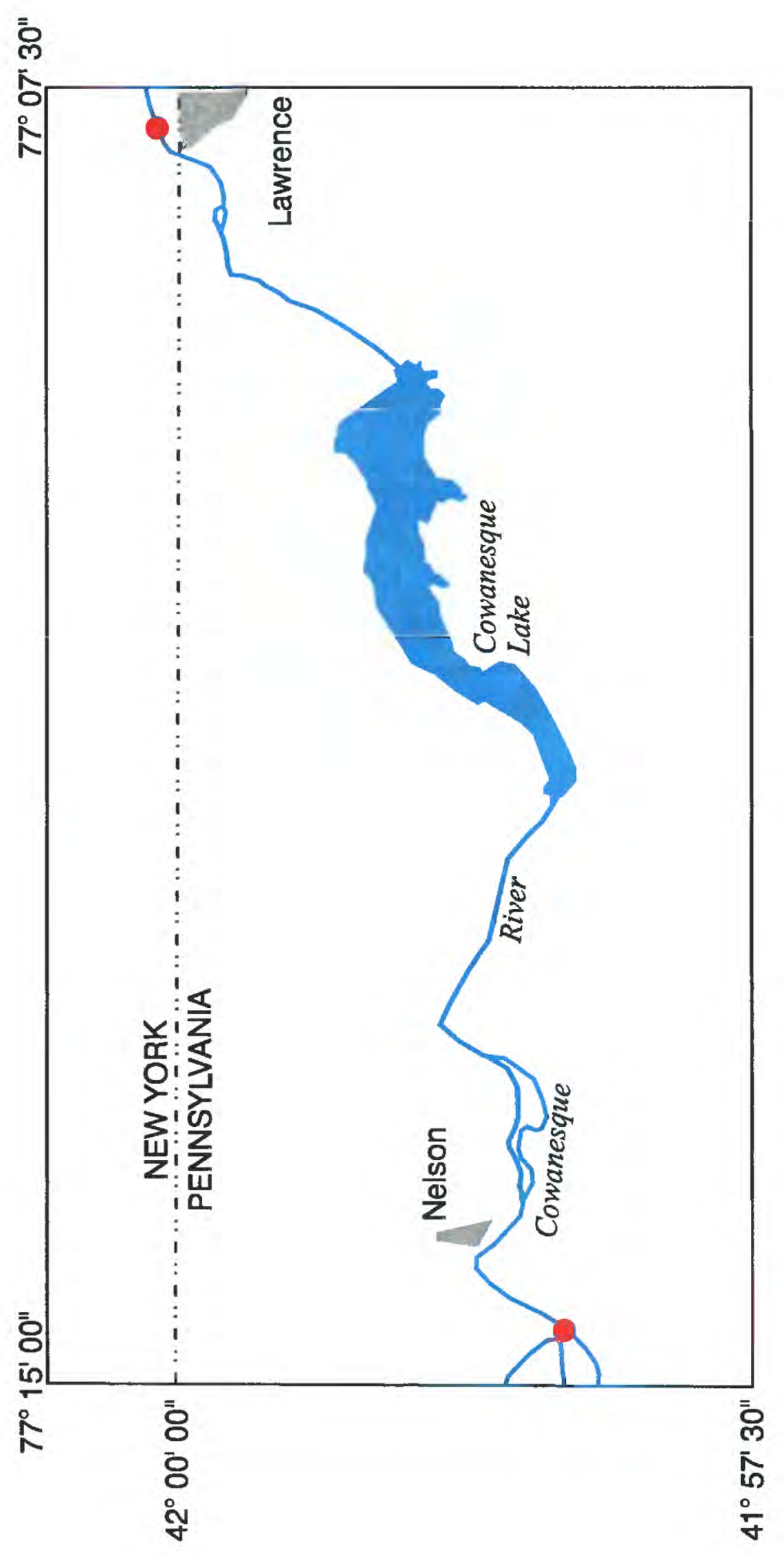

옹
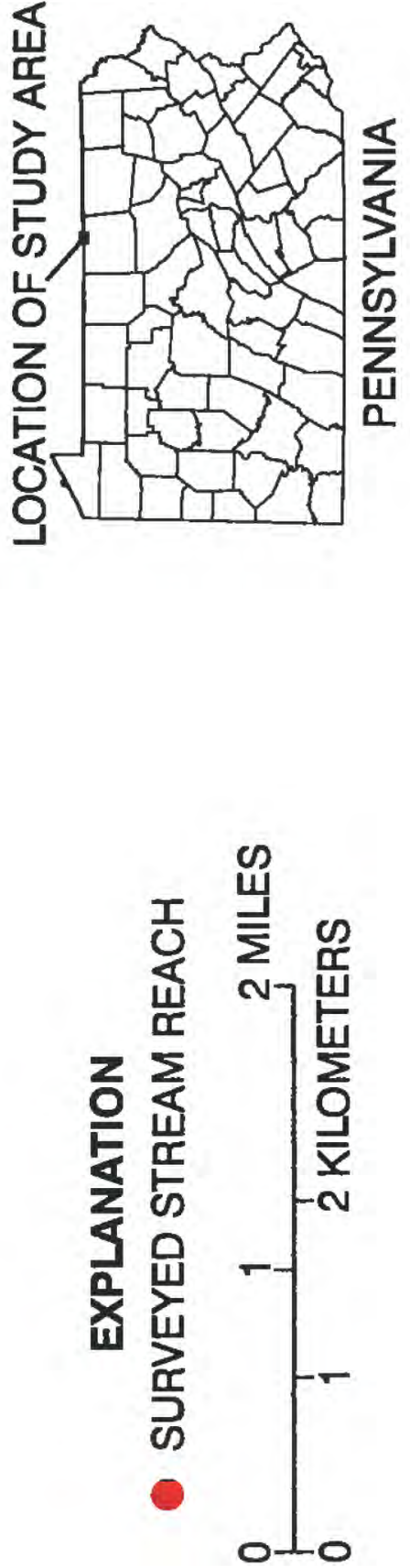

잉

E్

믐 


\section{STUDY METHODS}

The fish communities at the inflow and outflow of Cowanesque Lake were surveyed on September 15 and 16,1998. These communities were characterized by the total number of species collected and the relative abundance of each species. Habitat was assessed and related to the fish communities found in each reach.

\section{Fish Sampling}

A Coffelt Mark-10 backpack electroshocker incorporating pulsed direct current was used to collect fish at each sampling reach. Both reaches were wadable. A five person crew was used in both reaches. The backpack electroshocker, an electrode, and a net was carried by one person. The other individuals on the crew netted the fish and put them in buckets. The upstream reach was covered with a single pass of 4,406 seconds. To cover the downstream reach, two passes were conducted, requiring 5,244 seconds to complete. All passes were conducted in an upstream direction.

After each pass, the fish were placed in rubber tubs with aerators, sorted, and identified to species using texts to confirm identifications (Page and Burr, 1991). A maximum of 25 individuals per species were weighed (grams), measured for total and standard lengths (millimeters), and examined for external anomalies (Meador and others, 1993). After 25 individuals of a species were weighed and measured, the remaining fish were counted and mass weighed to the nearest gram. A summary of the fish data can be found in the Appendix. A few specimens were put in 10-percent buffered formaldehyde for a voucher collection and verification in the USGS laboratory in Lemoyne, $\mathrm{Pa}$. At the downstream reach, the fish from the first pass were placed in a live cage away from the reach being shocked to protect these fish from further trauma. After both passes were completed, the fish not retained for voucher specimens were released back into the river.

\section{Habitat Quantification}

Habitat assessment was conducted according to the Rapid Bioassessment Protocols (RBP) (Barbour and others, 1997). The riffle and run prevalence data form was used. Twelve criteria were used to assess the quality of the fish habitat. Each criterion is rated on a score of 1 to 20 . These scores were summed for a total habitat score. An average was then calculated and assessment was made on this averaged score. A score of $0-5$ is poor, 6-10 is marginal, 11-15 is suboptimal, and 16-20 is optimal (Klemm and Lazorchak, 1995). A reach with a higher habitat score should, theoretically, support a healthier fish community than a reach with a lower habitat score.

\section{Data Analysis}

The numbers of fish and their weights were totaled by species. The catch-per-unit-effort (CPUE) was calculated by dividing the number of fish collected by the total electroshocking time (Nielsen and Johnson, 1983). CPUE was used to compare the number of fish collected at each reach for the amount of time used for the effort. A higher CPUE would show more fish in an area than a lower CPUE. The reach with the lower CPUE is typically considered to be more impaired than a reach with a higher CPUE (Nielsen and Johnson, 1983). 
Four indices were generated to further assess the health of the fish communities found in these reaches. The Shannon Index $\left(\mathrm{H}^{\prime}\right)$ is a value that combines species richness and evenness where $>3.99$ can be considered non-impacted; 3.00-3.99, slightly impacted; 2.00-2.99, moderately impacted; and <2.00, severely impacted (Bode and others, 1993). This calculation gives one estimate of the health of the entire fish community in each reach. A Jaccard Coefficient of Similarity and an Index of Similarity (Klemm and others, 1990) measure community similarity using the species present in both reaches and those found only in one reach or the other. These index scores can range between 0.0 and 1.0, reaching 1.0 as the similarities between reaches increases (Plafkin and others, 1989). The fourth index is an Index of Biotic Integrity (IBI). The Maryland IBI for non-coastal streams (Roth and others, 1997) was used because Pennsylvania and New York do not have an IBI currently in place. The IBI score is used to measure the health of a fish community, taking into consideration the number of native species, feeding habits of the species present, and their tolerance or intolerance to water pollution and sediment. The first two metrics for the IBI, number of native species and number of benthic species, are adjusted for watershed areas using the formula in Roth and others (1997). A numeric scale where 1.0-1.9 is very poor, 2.0-2.9 is poor, 3.0-3.9 is fair, and 4.0-5.0 is good (Roth and others, 1997) is used to show the health of the community. These indices, in combination with the CPUE, are used to show any differences between the fish communities in the reaches surveyed, to determine if the fish communities show any impairment, and to aid in assessing if differences seen in the communities are related to the impoundment.

When this work began, there was an understanding that a statewide IBI would be available by the time data analyses were initiated. Unfortunately, this was not the case. Because the state of New York also did not have an IBI in place, the well researched and highly tested model developed by the Maryland Biological Stream Survey (MBSS) was selected. The use of regional IBI's has been endorsed by Miller and others (1988) and use of regional reference sites by Hughes and others (1986). These studies indicate that when geographically specific IBI's or reference conditions are not available, reasonably comparative conditions from ecologically similar areas may be used.

Although somewhat geographically distant, the fish faunal assemblages of Maryland were thought to better represent the Susquehanna River Basin drainage than the species depauperate northeastern region. The Northern Highland ecoregion is common to both the study area and the area where the metrics were developed. Many metrics included in all multi-metric scoring systems seem to have 4-5 core metrics that explain much of the classification efficiency of the index. The remaining metrics add redundancy to insure a strong mathematical signal is developed. For example, 4 of the 12 metrics in the original IBI (Karr, 1981) respond to sediment.

The Maryland area where the IBI was developed may not be locally specific, but it does include the historical unit of the Susquehanna River drainage. The IBI also includes many sites, covers many species collected in the study area, and very importantly is adjusted for basin size. It is the logical alternative to use under these conditions. 


\section{FISH-COMMUNITY COMPOSITION}

A total of 11 species were collected upstream of Cowanesque Lake with a calculated CPUE of 6.7 (table 1), an $\mathrm{H}^{\prime}$ of 2.69 (table 1), an IBI of 4.3 (table 2), and a habitat score of 151 (table 3). A total of 22 species were collected downstream with a calculated CPUE of 7.4 (table 1), an $\mathrm{H}^{\prime}$ of 3.36 (table 1), an IBI of 3.8 (table 2), and a habitat score of 168 (table 3). A Jaccard Coefficient of Similarity of 0.32 and an Index of Similarity of 0.48 showed these communities are different. Detailed information about the species is in the Appendix. The sculpins were only identified to genus because of the difficulty in differentiating among sculpin species in the field.

Table 1. Taxa list, number of individuals, and total and average weights by species for fish communities upstream and downstream of Cowanesque Dam, Pa., 1998

[-, not collected in this sample]

\begin{tabular}{|c|c|c|c|c|}
\hline \multirow[b]{2}{*}{ Species name } & \multicolumn{2}{|c|}{ Upstream reach } & \multicolumn{2}{|c|}{ Downstream reach } \\
\hline & $\begin{array}{l}\text { Numbers of } \\
\text { individuals }\end{array}$ & $\begin{array}{l}\text { Species } \\
\text { total weight, } \\
\text { in grams }\end{array}$ & $\begin{array}{l}\text { Number of } \\
\text { individuals }\end{array}$ & $\begin{array}{l}\text { Species } \\
\text { total weight, } \\
\text { in grams }\end{array}$ \\
\hline Central stoneroller, Campostoma anomalum & 9 & 131 & 14 & 117 \\
\hline Spotfin shiner, Cyprinella spiloptera & - & - & 1 & 2 \\
\hline Common carp, Cyprinus carpio & - & - & 5 & 6,296 \\
\hline Cutlips minnow, Exoglossum maxillingua & 152 & 1,060 & - & - \\
\hline River chub, Nocomis micropogon & 2 & 27 & - & - \\
\hline Comely shiner, Notropis amoenus & - & - & 1 & 4 \\
\hline Spottail shiner, Notropis hudsonius & - & - & 1 & 3 \\
\hline Bluntnose minnow, Pimephales notatus & - & - & 92 & 221 \\
\hline Blacknose dace, Rhinichthys atratulus & - & - & 6 & 12 \\
\hline Longnose dace, Rhinichthys cataractae & 36 & 90 & 46 & 231 \\
\hline Creek chub, Semotilus atromaculatus & 4 & 9 & 1 & 4 \\
\hline Fallfish, Semotilus corporalis & - & - & 14 & 73 \\
\hline White sucker, Catostomus commersoni & 55 & 1,441 & 111 & 30,146 \\
\hline Northern hog sucker, Hypentelium nigricans & 12 & 1,536 & - & - \\
\hline Margined madtom, Noturus insignis & 27 & 232 & 1 & 2 \\
\hline Chain pickerel, Esox niger & - & - & 1 & 22 \\
\hline Sculpin, Cottus spp. & - & - & 3 & 34 \\
\hline Rock bass, Ambloplites rupestris & 10 & 113 & 19 & 1,190 \\
\hline Pumpkinseed, Lepomis gibbosus & - & - & 50 & 426 \\
\hline Smallmouth bass, Micropterus dolomieu & 128 & 1,687 & 1 & 105 \\
\hline Black crappie, Pomoxis nigromaculatus & - & - & 1 & 21 \\
\hline Tessellated darter, Etheostoma olmstedi & 57 & 92 & 119 & 301 \\
\hline Banded darter, Etheostoma zonale & - & - & 27 & 68 \\
\hline Yellow perch, Perca flavescens & - & - & 53 & 428 \\
\hline Shield darter, Perca peltata & - & - & 79 & 296 \\
\hline Totals & 492 & 6,418 & 646 & 40,002 \\
\hline Total number of species & 11 & & 22 & \\
\hline $\begin{array}{l}\text { CPUE (number of individuals per shocking } \\
\text { time in minutes) }\end{array}$ & 6.7 & & 7.4 & \\
\hline $\mathrm{H}^{\prime}$ (Shannon Index) & 2.69 & & 3.36 & \\
\hline
\end{tabular}


Table 2. IBI score for fish communities upstream and downstream of Cowanesque Dam, Pa., 1998 [4.0-5.0, good; 3.0-3.9, fair; 2.0-2.9, poor; 1.0-1.9, very poor (Roth and others, 1997)]

\begin{tabular}{lcc}
\hline \multicolumn{1}{c}{ IBI metric $^{1}$} & Upstream reach & Downstream reach \\
\hline Number of native species (adjusted value) & 5 & 5 \\
Number of benthic species (adjusted value) & 5 & 5 \\
Percent tolerant individuals & 5 & 5 \\
Percent abundance of dominant species & 5 & 5 \\
Percent generalists, omnivores, and invertivores & 3 & 1 \\
Percent insectivores & 5 & 3 \\
Number of individuals per square meter & 1 & 1 \\
Percent lithophilic spawners & 5 & 5 \\
\hline \multicolumn{1}{c}{ Average IBI score } & 4.3 & 3.8 \\
\hline
\end{tabular}

${ }^{1}$ Roth and others, 1997.

Table 3. Habitat assessment upstream and downstream of Cowanesque Dam, Pa., 1998 [0-5, poor; 6-10, marginal 11-15, suboptimal, 16-20, optimal]

\begin{tabular}{lcc}
\hline \multicolumn{1}{c}{ Habitat parameter $^{1}$} & Upstream reach & Downstream reach \\
\hline Instream fish cover & 11 & 12 \\
Epifaunal substrate & 15 & 10 \\
Embeddedness & 17 & 15 \\
Velocity/depth regimes & 17 & 15 \\
Channel alteration & 10 & 15 \\
Sediment deposition & 14 & 15 \\
Frequency of riffles & 15 & 6 \\
Channel flow status & 8 & 17 \\
Condition of banks & 12 & 18 \\
Bank vegetative protection & 12 & 18 \\
Grazing or other disruptive pressure & 10 & 15 \\
Riparian vegetative zone width & 10 & 12 \\
\hline \multicolumn{1}{c}{ Total score } & 151 & 168 \\
\multicolumn{1}{c}{ Average score } & 13 & 14 \\
\hline
\end{tabular}

${ }^{1}$ Klemm and Lazorchak, 1995. 


\section{Upstream Reach}

The fish community in the reach upstream of the reservoir is in good condition as shown by the IBI. The community is moderately impacted according to the $\mathrm{H}^{\prime}$ score. The habitat is suboptimal and of lesser quality than the reach downstream of the reservoir. Banks are less stable, which corresponds with the high frequency of riffles and higher velocities in the reach (table 3). The species collected in this reach are typically found in areas with boulders and little vegetation (Cooper, 1983; Page and Burr, 1991; Rohde and others, 1994; Smith, 1985). There is less embeddedness in this reach than downstream, and there is aquatic vegetation downstream that is not seen in the upstream reach. Vegetation cannot grow on bedrock and areas where little sediment covers the stream bottom.

The dominant species collected in this reach was cutlips minnow. This species is reported to remove the eyes of other fish (Smith, 1985; Jenkins and Burkhead, 1994). This behavior seems to be brought on by crowding and is a territorial response (Jenkins and Burkhead, 1994). Observation of the rock bass and smallmouth bass in this reach showed greater than 50 percent of these fish were missing at least one eye. Blackspot, parasites, or leeches were observed on 7 of the 11 species in this reach. These anomalies show an inconsistent relation with water quality and are therefore recorded but not typically used in assessment of water quality when using IBI scores (Simon, 1999).

Cutlips minnow, river chub, and northern hog sucker were collected upstream but not downstream of the dam. These species are typical in clear waters with gravel, rubble, and boulder substrate (Rohde and others, 1994). The northern hog sucker is considered a clean-stream indicator (Cooper, 1983) and is rarely found in areas with heavy siltation, pollution, or channel modification (Smith, 1979; Trautman, 1981). The CPUE and the diversity of the upstream reach were lower than that of the reach downstream of the reservoir.

\section{Downstream Reach}

The fish community in this reach is in fair condition as shown by the IBI. The $\mathrm{H}^{\prime}$ score indicates this community is more diverse than the community in the upstream reach and is only slightly impacted. The CPUE was higher here than upstream of the reservoir. Twenty-two species were collected in this reach; 14 of these species were not collected in the upstream reach. The habitat was suboptimal but ranked higher than the upstream habitat. The frequency of riffles was the lowest scoring downstream habitat criterion (table 3). This reach displayed a variety of habitats, including pooled areas under the bridge and around woody snags, and aquatic vegetation along the left edge of water, that were not found upstream.

Of the 14 species collected exclusively downstream, 5 of these had a relative abundance of 5 percent or greater-bluntnose minnow, pumpkinseed, banded darter, yellow perch, and shield darter. These species are typical near vegetative cover (Jenkins and Burkhead, 1994; and Page and Burr, 1991). Bluntnose minnow, pumpkinseed, and yellow perch are typical in quiet waters of pools and backwaters (Jenkins and Burkhead, 1994; Rohde and others, 1994), and yellow perch also are intolerant of pollutants and siltation (Rohde and others, 1994). Banded and shield darters are typical of moderate gradient streams with riffles and runs, areas without heavy siltation, and around submerged aquatic vegetation (Cooper, 1983; Page and Burr, 1991). By regulating flow out of the dams, normal fluctuations of flow and temperature are removed in downstream reaches, which promotes the growth of aquatic vegetation (Hynes, 1970) with which these fish are commonly associated. Dams also allow for suspended sediment to settle out of the water column and improve the clarity of streams downstream (Hynes, 1970). However, little difference was seen in embeddedness or sediment deposition between the two reaches (table 3 ). Of the 14 exclusive species, 9 of these species are collected from impoundments as well as streams (Cooper, 1983; Jenkins and Burkhead, 1994; Page and Burr, 1991; Rohde and others, 1994; Smith, 1985). Anomalies were observed in less than 10 percent of the fish in the downstream reach. 
The downstream reach was wider than the upstream reach and no bedrock was present. However, there were pools, aquatic vegetation, and woody snags, along with riffle and run areas that provide multiple habitats where a greater diversity of fish species survive. The downstream community has a lower IBI than upstream, but $\mathrm{H}^{\prime}$ showed the community downstream as being more diverse. More species were collected downstream (22) than upstream (11) of the reservoir. This accounts for the higher $\mathrm{H}^{\prime}$ score. The lower IBI score of the downstream reach is a consequence of the lower percentage of generalists, omnivores, invertivores, and insectivores there. These were the only differences between the IBI scores of the reaches.

The Jaccard Coefficient and the Index of Similarity showed the upstream and downstream communities are different. Northern hog sucker and yellow perch are suggestive of good water quality; one is present upstream and one downstream of the dam. Some species present downstream exhibit a preference for pooled rivers and lakes. The reach sampled below the dam had more pooled area than the upstream reach where these lake species may be able to exist. Some of these species could be from the reservoir and survive in the stream because dams can alter riverine environments and change them to lacustrine ones (Jenkins and Burkhead, 1994). A species list of the fish collected in the reservoir would be needed to make an accurate assessment.

The downstream reach of the Cowanesque River has more pooled areas than the upstream reach, where the water is slower moving and deeper than found in riffle areas. Different species of fish inhabit these larger, deeper pools than the riffles. Flow in the downstream reach of the dam is augmented during summer months to provide the towns downstream with an adequate drinking water supply (U.S. Army Corps of Engineers, website accessed May 4, 1999). Water temperature decreases by $2^{\circ} \mathrm{C}$ from upstream to downstream of the dam. The $\mathrm{pH}$ was 7.1 upstream and 6.7 downstream. Temperature and $\mathrm{pH}$ of the two reaches cannot explain the community differences seen. The water-quality property that shows the most significant change is specific conductance. The change was from 403 to $206 \mu \mathrm{S} / \mathrm{cm}$, upstream and downstream, respectively. The differences seen in the fish community appear to be related to the previously discussed habitat and not to differences in water quality.

The dam was built to protect the towns downstream from periodic flooding, to augment flow of the Cowanesque River, and to provide an adequate water supply for the towns along the river (U.S. Army Corps of Engineers, Civil Works Project Information, website accessed May 4, 1999). The uniform flow that a dam provides is typically not favorable to native fishes that need high spring flows for spawning and can survive summer low-flow conditions (Moyle, 1976; Baltz and Moyle, 1993; Strange and others, 1992). The drought effects noted in the upstream reach were not noted downstream of the dam because of the flow augmentation. It has been documented that the flow from a dam can prevent flooding and drought conditions downstream of the dam but cannot affect the upstream reaches of a river (Hynes, 1970).

The community downstream consists of a greater number of generalist feeding species than are found upstream. This is an indication that habitat types are diverse (Halliwell and others, 1999) and can be characteristic of degraded habitat (Fausch and others, 1990). More species can inhabit the downstream reach because of the variety in habitat types. Only a few fish species can live and reproduce in the riffle habitat found in the upstream reach, while in the varied habitats downstream, many more species can live and reproduce. The generalist feeding fish species are typically found downstream of dams because dams retain the normal energy source of the stream by trapping coarse and fine particulate organic matter in the reservoir (Vannote and others, 1980). This energy source is needed for native, specialist species to exist. Both the dam and habitat differences can affect the fish-community structure downstream and cause the native community, which may have been similar to the upstream community, to be replaced. 
Whether or not some habitat features, such as stream width and depth, were always different or were changed after the dam was built must still be addressed with comparison to pre-impoundment studies of the fish communities and habitat. More in-depth analysis of the historical data may give clues to why these communities are different. This comparison is outside the scope of the report.

\section{SUMMARY}

Two reaches of the Cowanesque River, which flows in and out of Cowanesque Lake, were studied to evaluate the current status of fish communities in the vicinity of the reservoir. The study was conducted to determine the similarities and differences in fish communities above and below the reservoir in 1999 and to identify any possible effects the dam could have on these communities.

A survey conducted on September 15 and 16, 1998, showed the fish communities to be in good condition upstream and fair condition downstream of the reservoir based on IBI scores. The downstream community had twice as many species as upstream, a higher Shannon Index, and a higher CPUE. The fish downstream are more generalist feeders; those upstream are more insectivorous feeders. This would make the IBI upstream higher. The other individual IBI metrics were the same for both reaches.

The fish communities in the two reaches surveyed were different according to the Jaccard Coefficient and the Index of Similarity. The species downstream are typical in reservoirs and larger, slower moving waters and in areas where there is submerged aquatic vegetation. The upstream species are typical in faster moving waters and in waters with little or no aquatic vegetation.

Instream habitat differed significantly between the upstream and downstream reaches. The geomorphic channel unit upstream of the reservoir is bedrock riffles and cobble, boulder runs; the geomorphic channel unit downstream was riffle, run, and pool with a predominantly cobble and gravel stream bottom. The downstream reach was wider and other streams flowed into the segment of stream between the two reaches. These habitat differences can influence the structure of the fish communities seen in the reaches.

Historically, the communities in these reaches may have been different because of naturally occurring habitat differences, the falls upstream, and the input from the other streams entering the river segment between the two sampling sites. Alternatively, the regulation of the flow from the dam may have altered the downstream habitat. This can not be determined from this survey alone. 


\section{REFERENCES CITED}

Baltz, D.M., and Moyle, P.B., 1993, Invasion resistance to introduced species by a native assemblage of stream fishes: Ecological Applications, v. 3, 9.p.

Barbour, M.T., Gerritsen, J., Snyder, B.D., Stribling, J.B., 1997, Revision to rapid bioassessment protocols for use in streams and rivers-Periphyton, benthic macroinvertebrates, and fish: Washington, D.C., U.S. Environmental Protection Agency, EPA/841-D-97-002, 306 p., 4 appendices.

Bode, R.W., Novak, M.A., and Abele, L.E., 1993, 20 year trends in water quality of rivers and streams in New York State based on macroinvertebrate data, 1972-1992: Albany, N.Y., NYS Department of Environmental Conservation, $217 \mathrm{p}$.

Cooper, E.L., 1983, Fishes of Pennsylvania and the Northeastern United States: University Park, Pa., The Pennsylvania State University Press, 243 p.

Fausch, K.D., Lyons, J., Karr, J.R., and Angermeier, P.L., 1990, Fish communities as indicators of environmental degradation, in Adams, S.M., ed., 1990, Biological indicators of stress in fish: Bethesda, Md., American Fisheries Society Symposium Number 8, 21 p.

Halliwell, D.B., Langdon, R.W., Daniels, R.A., Kurtenbach, J.P., and Jacobson, R.A., 1999, in Simon, T.P., ed., Assessing the sustainability and biological integrity of water resources using fish communities: Boca Raton, CRC Press, $671 \mathrm{p}$.

Hughes, R.M., Larsen, D.P., Omernik, J.M., 1986 Regional reference sites-A method for assessing stream pollution: Environmental Management, v. 10,7 p.

Hynes, H.B.N., 1970, The ecology of running waters: Liverpool, Liverpool University Press, 555 p.

Jenkins, R.E., and Burkhead, N.M., 1994, Freshwater fishes of Virginia: Bethesda, Md., American Fisheries Society, $1079 \mathrm{p}$.

Karr, J.R., 1981, Assessment of biotic integrity using fish communities: Fisheries, v. 6(6), 7 p.

Klemm, D.J., Lewis, P.A., Fulk, F., and Lazorchak, J.M., 1990, Macroinvertebrate field and laboratory methods for evaluating the biological integrity of surface waters: Cincinnati, Ohio, U.S. Environmental Protection Agency, EPA/600/4-90/030, 256 p.

Klemm, D.J., and Lazorchak, J.M., 1995, Environmental monitoring and assessment program, surface waters - field operations and methods for measuring the ecological condition of wadable streams: Cincinnati, Ohio, U.S. Environmental Protection Agency, EPA/620/12094/004, 130 p., 9 appendices.

Meador, M.R., Cuffney, T.F., and Gurtz, M.E., 1993, Methods for sampling fish communities as part of the National Water-quality Assessment program: Raleigh, North Carolina, U.S. Geological Survey, Open-File Report 93-104, 38 p.

Miller, D.L., Leonard, P.M., Hughes, R.M., Karr, J.R., Moyle, P.B., Schrader, L.H., Thompson, B.A., Daniel, R.A., Fausch, K.D., Fitzhugh, G.A., Gammon, J.R., Halliwell, D.B., Angermeier, P.L., and Orth, D.J., 1988 , Regional applications of an index of biotic integrity for use in water resource management: Fisheries, v. 13(5), 9 p.

Moyle, P.B., 1976, Inland fishes of California: Berkley, University of California Press, 405 p.

Nielsen, L.A., and Johnson, D.L., eds., 1983, Fisheries techniques: Bethesda, Md., American Fisheries Society, $468 \mathrm{p}$.

Page, L.M., and Burr, B.M., 1991, Peterson field guide to freshwater fishes: New York, Houghton Mifflin Company, $432 \mathrm{p}$.

Plafkin, J.L., Barbour, M.T., Porter, K.D., Gross, S.K., and Hughes, R.M., 1989, Rapid bioassessment protocols for use in streams and rivers - benthic macroinvertebrates and fish: Washington, D.C., U.S. Environmental Protection Agency, EPA/440/4-89/001, 128 p., 4 appendices.

Rohde, F.C., Arndt, R.G., Lindquist, D.G., and Parnell, J.F., 1994, Freshwater fishes of the Carolinas, Virginia, Maryland, and Delaware: Chapel Hill, N.C., The University of North Carolina Press, 222 p. 


\section{REFERENCES CITED-Continued}

Roth, N.E., Southerland, M.T., Chaillou, J.C., Vølstad, J.H., Weisberg, S.B., Wilson, H.T., Heimbuch, D.G., and Seibel, J.C., 1997, Maryland biological stream survey - ecological status of non-tidal streams in six basins sampled in 1995: Linthicum, Md., Versar, Inc., Columbia, Md. and Coastal Environmental Services, Chesapeake Bay and Watershed Programs Monitoring and Non-tidal Assessment, CBWPMANTA-EA-97-2. 151 p., 6 appendices.

Simon, T.P., 1999, Assessing the sustainability and biological integrity of water resources using fish communities: Boca Raton, Fla., CRC Press, 671 p.

Smith, C.L., 1985, The inland fishes of New York State: Albany, N.Y., New York State Department of Environmental Conservation, $522 \mathrm{p}$.

Smith, P.W., 1979, The fishes of Illinois, Urbana, Ill., University of Illinois Press, 314 p.

Strange, E.M., Moyle, P.B., and Foin, T.C., 1992, Interactions between stochastic and deterministic processes in stream fish community assembly: Environmental Biology of Fishes, v. 36, 15 p.

Trautman, M.B., 1981, The fishes of Ohio with illustrated keys, revised edition: Columbus, Oh., Ohio State University Press, $683 \mathrm{p}$.

U.S. Army Corps of Engineers, Civil Works Project Information: accessed May 4, 1999, at URL http://crunch.tec.army.mil/dpn/webpages/DPN_Detail.CFM?ID=1435/.

Vannote, R.L., Minshall, G.W., Cummins, K.W., Sedell, J.R., and Cushing, C.E., 1980, The river continuum concept: Canadian Journal of Fisheries and Aquatic Science, v. 37, 7 p.

Ward, J.R., 1976, Preliminary results of preimpoundment water-quality studies in the Tioga River Basin, Pennsylvania and New York: U.S. Geological Survey Water-Resources Investigations Report 76-66, $77 \mathrm{p}$. 


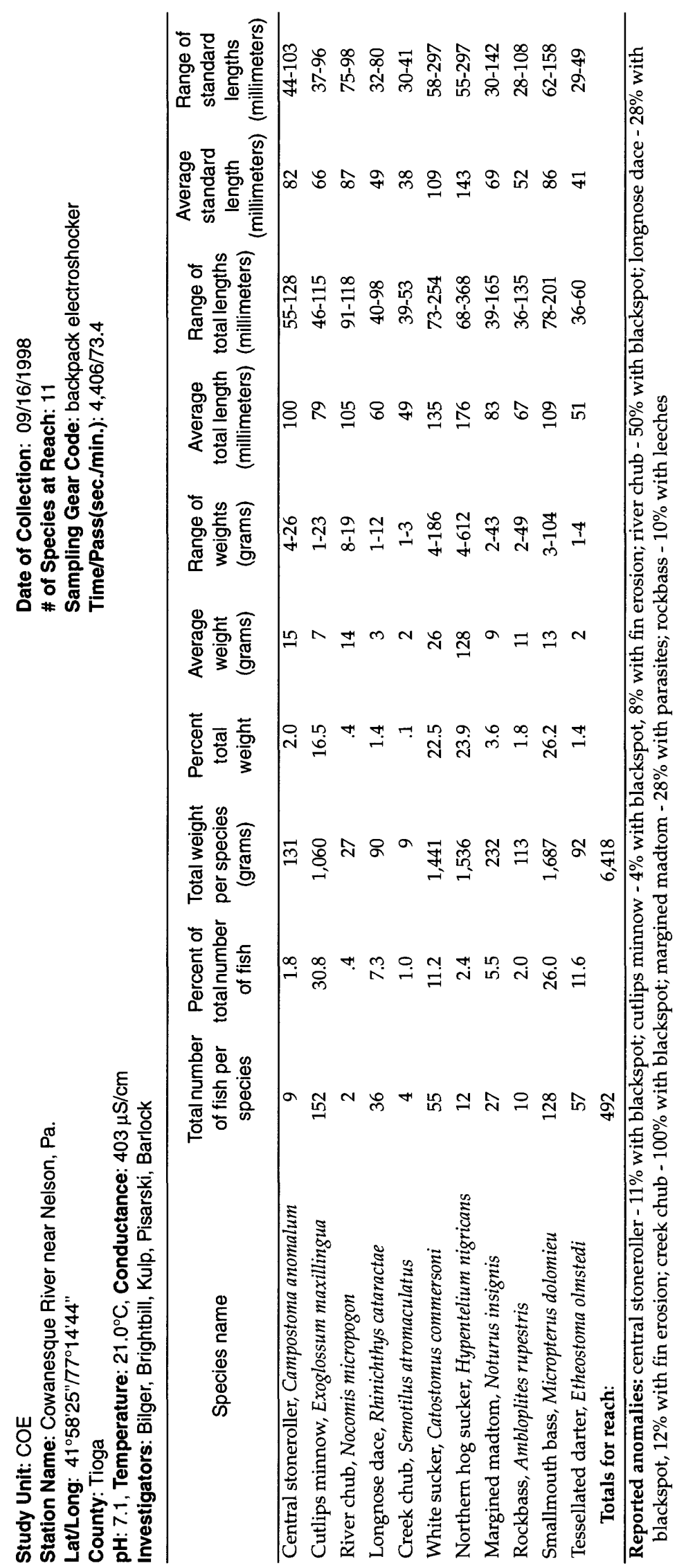




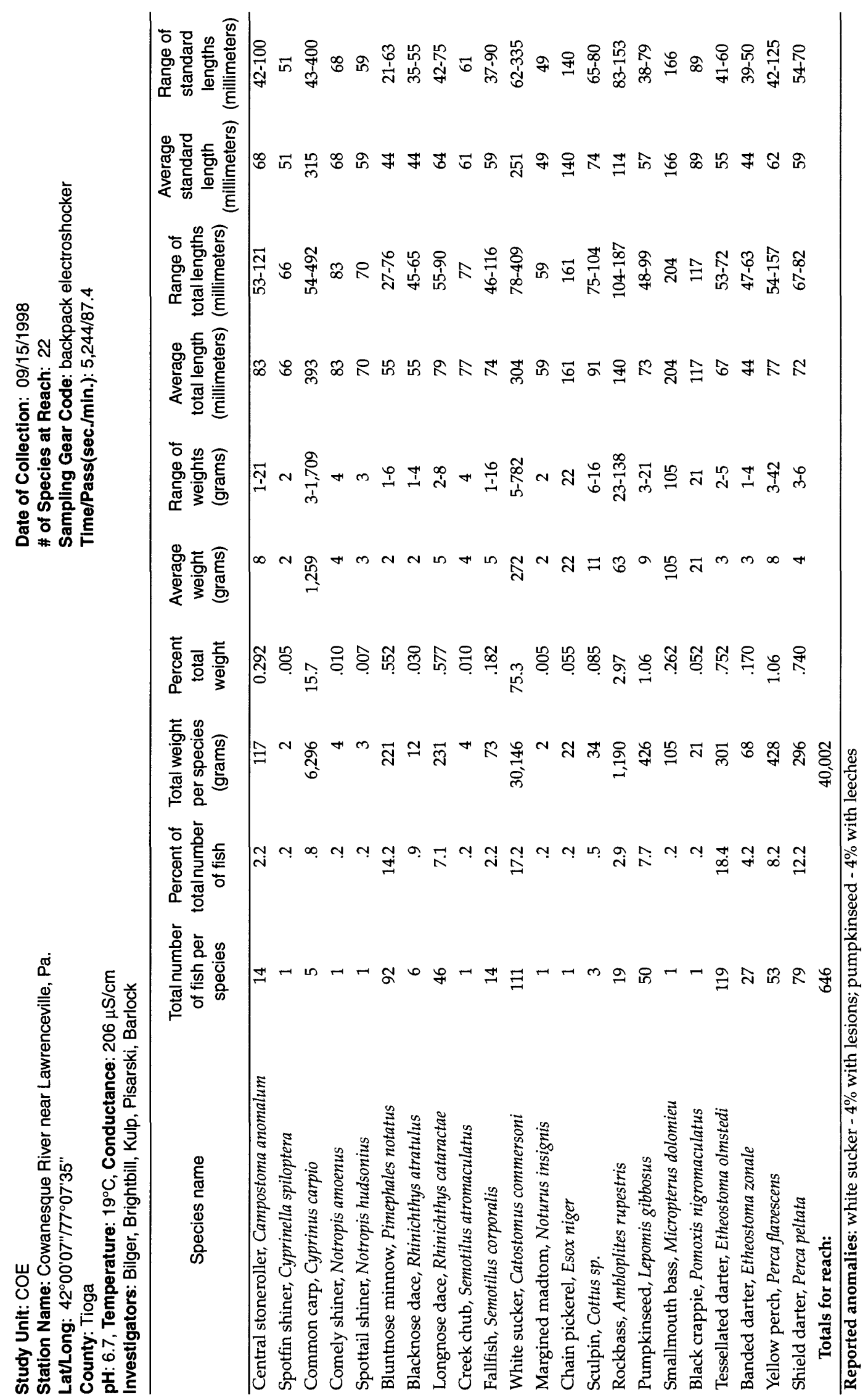

